\title{
Holocene variations in the Asian monsoon inferred from the geochemistry of lake sediments in central Tibet
}

\author{
Carrie Morrill $^{\text {a,* }}$, Jonathan T. Overpeck ${ }^{\text {a,b }}$, Julia E. Cole ${ }^{\text {a }}$, Kam-biu Liu ${ }^{\text {c }}$, \\ Caiming Shen ${ }^{c}$, Lingyu Tang ${ }^{\mathrm{d}}$ \\ ${ }^{a}$ Geosciences Department, Gould-Simpson Building, University of Arizona, Tucson, AZ 85721, USA \\ ${ }^{\mathrm{b}}$ Institute for the Study of Planet Earth, 715 N. Park Avenue (2nd Floor), University of Arizona, Tucson, AZ 85721, USA \\ ${ }^{\mathrm{c}}$ Department of Geography and Anthropology, Louisiana State University, Baton Rouge, LA 70803, USA \\ ${ }^{\mathrm{d}}$ Nanjing Institute of Geology and Paleontology, Chinese Academy of Sciences, Nanjing 210008, China
}

Received 20 June 2004

Available online 2 February 2006

\begin{abstract}
We present a record of monsoon variations for the early and middle Holocene that is inferred from the geochemistry of sediment cores from Ahung Co, a lake in central Tibet. The resolution of this record is better than $50 \mathrm{yr}$ and the age model is derived from radiocarbon ages of terrestrial charcoal, which eliminates errors associated with the lake hard-water effect. We made down-core geochemical measurements of \% carbonate, $\%$ organic carbon, $\mathrm{C} / \mathrm{N}$ and $\delta^{13} \mathrm{C}$ of bulk organic matter, $\delta^{13} \mathrm{C}$ and $\delta^{18} \mathrm{O}$ of carbonate, and \% dolomite. Proxy calibration and modern water-balance reconstruction show that these are proxies for lake depth and the amount of monsoon precipitation. We find that lake level and monsoon precipitation have been decreasing at Ahung Co since the early Holocene ( $7500 \mathrm{cal}$ yr B.P.). Superimposed on this trend are rapid declines in monsoon rainfall at 7000-7500 and $4700 \mathrm{cal}$ yr B.P. and seven century-scale wet-dry oscillations. The cores do not contain sediment from the last $\sim 4000 \mathrm{yr}$. Surface sediments from the lake accumulated during the 20th century, however. From this, we argue that lake levels have risen again recently following a late Holocene dry period.
\end{abstract}

(C) 2005 University of Washington. All rights reserved.

Keywords: Precipitation; Monsoon; Holocene; Climate change; Oxygen stable isotopes; Paleoclimate; Hard-water effect; Aquatic macrophytes

\section{Introduction}

The Asian summer monsoon is one of the most important components of Earth's climate system. Monsoon extremes cause flooding and droughts that impact nearly half of the world's population. In addition, the Asian monsoon may affect climate globally, through interactions with El Niño (e.g., Shukla and Paolino, 1983; Liu et al., 2000) and mid-latitude circulation (e.g., Wang et al., 2001).

It is well established that the Asian monsoon weakened through the Holocene in response to the gradual decrease in summer insolation (e.g., Prell and Kutzbach, 1992; Overpeck et al., 1996; An et al., 2000) Recently, higher-resolution records

\footnotetext{
* Corresponding author. Current address: Climate and Global Dynamics Division, National Center for Atmospheric Research, 1850 Table Mesa Drive, Boulder, CO 80305, USA. Fax: +1 3034971348.

E-mail address: morrill@ucar.edu (C. Morrill).
}

have provided hints of abrupt climate transitions and fluctuations superimposed upon this gradual trend (e.g., Gasse and Van Campo, 1994; Guo et al., 2000; Morrill et al., 2003; Overpeck et al., 2005). Resolution, age control and spatial coverage are, however, currently insufficient to develop a detailed picture of regional monsoon variability on decadal to century timescales.

In this research, we develop a century-scale record of monsoon variations during the early and middle Holocene based on the water-balance history of Ahung $\mathrm{Co}(\mathrm{Co}=$ lake $)$ in Tibet. Tibet is an excellent place to study the Asian monsoon for three reasons. First, the present-day limit of monsoon rainfall crosses Tibet, causing this region to be particularly sensitive to monsoon variations (Fig. 1). Second, the Tibetan Plateau plays an important role in initiating and maintaining the monsoon circulation. During the summer, a strong latitudinal temperature gradient exists in the upper troposphere due in part to heating of the atmosphere over the 

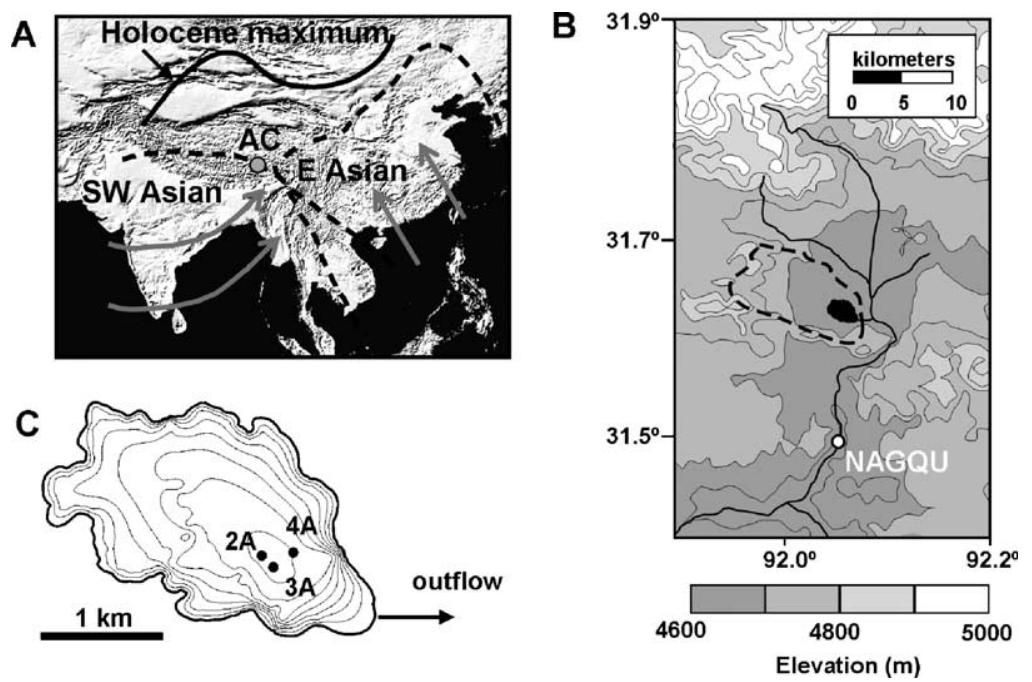

Figure 1. (A) Estimated present extent of southwest Asian and east Asian monsoons (Araguas-Araguas et al., 1998) and maximum extent of monsoons during Holocene (Winkler and Wang, 1993). (B) Ahung Co and surrounding area, contour interval is $100 \mathrm{~m}$, dashed line indicates extent of surface drainage basin and solid lines show rivers and streams. (C) Ahung Co bathymetry measured in July 2001, contour interval is $20 \mathrm{~cm}$ and circles show core locations.

plateau. This gradient fuels the monsoon circulation. Surface and climatic conditions on the plateau, which impact tropospheric heating, can play an important role in modulating the monsoon circulation (e.g., Barnett et al., 1988). Third, the environment of Tibet has been relatively undisturbed by human activities. Intensive agriculture and settlement in other parts of the monsoon region, including India and eastern China, add a complicating factor to proxy records (e.g., Hodell et al., 1999).

Despite the motivation for developing monsoon records from Tibet, few records exist from this region and those that do have uncertain age models. The age models of two Tibetan ice cores that span the Holocene were estimated by extrapolation of annual layer thickness and correlation to the GISP2 ice core (Thompson et al., 1989, 1997). Due to a lack of terrestrial macrofossils, age models for Tibetan lake records have been based on radiocarbon dates of aquatic material. These lakes have hard-water effects as large as 3200 yr (Fontes et al., 1996), however, and possible variations in the hard-water effect through time were not taken into account in every case (Gasse et al., 1991, 1996; Lister et al., 1991; Morinaga et al., 1993). This new record from Ahung Co has an accurate age model based on more than 50 radiocarbon dates of both aquatic material and terrestrial charcoal.

\section{Study area}

Ahung Co is a small $\left(3.6 \mathrm{~km}^{2}\right)$ freshwater lake located in the steppe of central Tibet $\left(31.62^{\circ} \mathrm{N}, 92.06^{\circ} \mathrm{E}\right)$. This region has relatively low topographic relief; the elevation of the lake is $4575 \mathrm{~m}$ and elevations in its drainage basin are up to $4900 \mathrm{~m}$ (Fig. 1). The area of the lake's surface drainage basin is about $100 \mathrm{~km}^{2}$. There are several streams that discharge water into the wetlands surrounding the lake, but none of these streams flow directly into the lake. Ahung Co has a small surface outlet and the lake level currently oscillates above and below the level of this outlet. Mean lake depth in July 2001 was about $1 \mathrm{~m}$ and maximum lake depth was about $1.5 \mathrm{~m}$.

The region surrounding Ahung Co is underlain by Mesozoic sedimentary and metasedimentary rocks (Chang et al., 1988). Outcrops in the basin consist of quartzite, shale and small amounts of dolomite. Vegetation in the basin consists of marsh meadows composed of Cyperaceae and steppe dominated by Artemisia and Stipa (Shen, 2003).

The mean annual air temperature in this area is about $-1.5^{\circ} \mathrm{C}$, and patches of permafrost are present in some locations (Wang and French, 1995). Average air temperature during January is about $-13^{\circ} \mathrm{C}$ and during July is about $9^{\circ} \mathrm{C}$. Annual precipitation is between 30 and $60 \mathrm{~cm}$, with about $80 \%$ falling from June to September during the summer monsoon.

A detailed water-balance study of Ahung Co and its drainage basin over the past $16 \mathrm{yr}$ showed that present-day water-balance fluctuations are caused primarily by variations in the amount of summer monsoon precipitation (Morrill, 2004). Decreased lake and basin evaporation during humid monsoon summers further amplifies the response of lake level to monsoon variations.

\section{Methods \\ Core collection}

We collected three sediment cores from Ahung Co during July 1995 and July 1999 using a modified Livingstone piston corer (Wright et al., 1984) and a floating platform. These cores, designated $2 \mathrm{~A}, 3 \mathrm{~A}$ and $4 \mathrm{~A}$, were collected from the deepest part of the lake, which was under about $1.5 \mathrm{~m}$ of water in July 2001 (Fig. 1). All three cores are $1 \mathrm{~m}$ long or less; an unidentified, unpenetrable layer exists below this depth. The main visual feature of each of these cores is a nearly identical pattern of alternations between layers dominated by the aquatic macrophyte Potamogeton and layers consisting primarily of lacustrine carbonate (Fig. 2). 


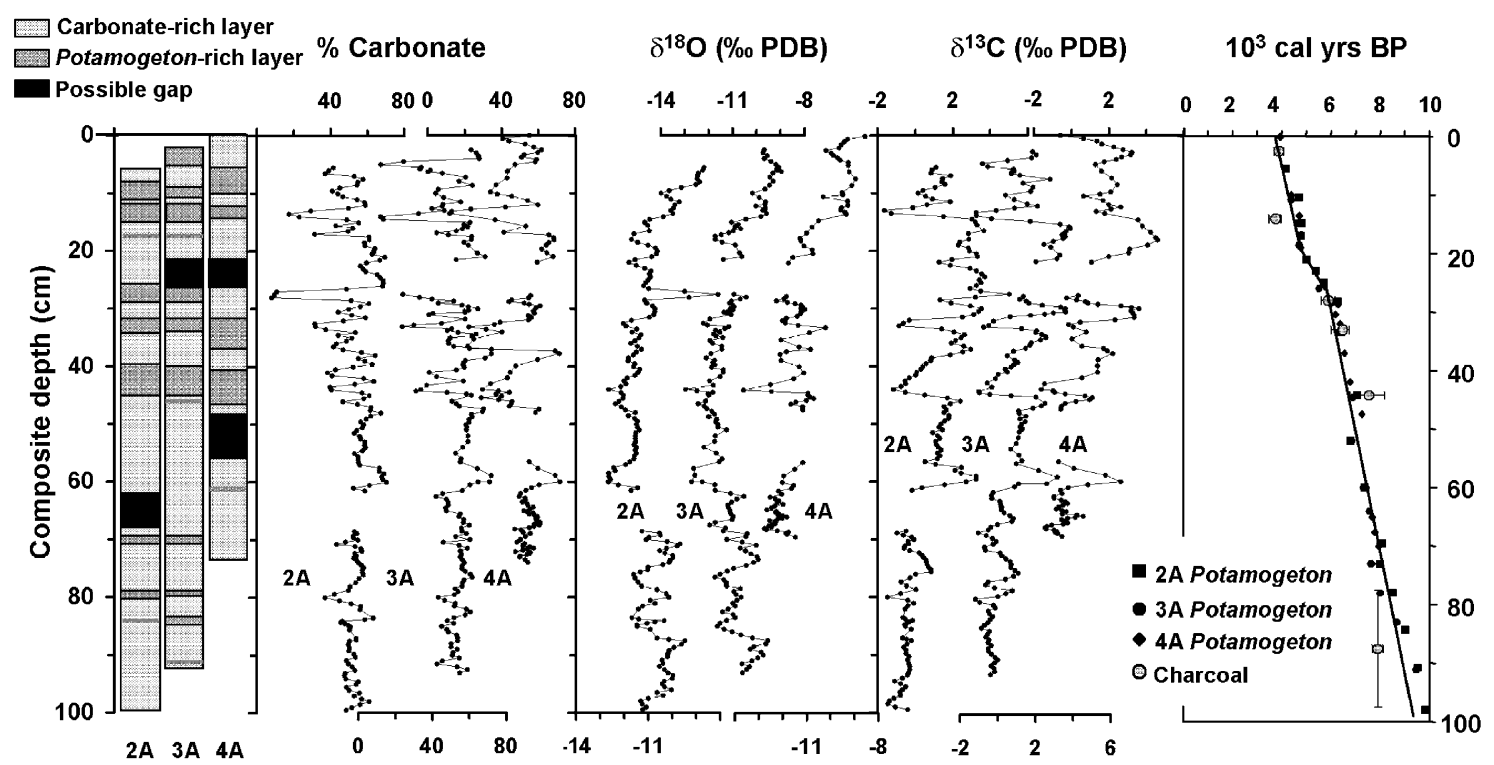

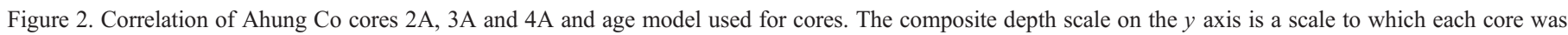
correlated. Gaps in the time-series indicate periods of erosion and/or non-deposition determined by curve matching of proxy time-series.

\section{Radiocarbon dating}

The bedrock in the basin of Ahung Co contains some carbonate rocks, including dolomite and shales with calcareous cement. Thus, we expect that radiocarbon ages of aquatic material are older than their actual time of deposition due to the lake hard-water effect (e.g., Deevey et al., 1954). This is confirmed from radiocarbon dates on living, submerged aquatic plants (Potamogeton spp.) collected from the lake in July 2001. In alkaline waters $(\mathrm{pH}>8)$ where aqueous $\mathrm{CO}_{2}$ is limited, these plants use bicarbonate for photosynthesis (Lucas et al., 1978) and their ages reflect the hard-water effect. Three samples of Potamogeton yield an average ${ }^{14} \mathrm{C}$ activity of $99.8 \%$ (Table 1 ). Given a ${ }^{14} \mathrm{C}$ activity of atmospheric $\mathrm{CO}_{2}$ in 2001 of $\sim 108 \%$ (S. Trumbore, unpublished data), the present hard-water correction for Potamogeton in Ahung Co is 600 to $700 \mathrm{yr}$.

To generate an age model that does not reflect the hard-water effect, we used terrestrial charcoal from core sediment. Charcoal was identified under a microscope and picked using tweezers. Due to the small amounts of charcoal in these cores, it was necessary to combine samples from corresponding intervals in multiple cores. We correlated the cores to the $1-\mathrm{cm}$ level using measurements of $\%$ carbonate, $\delta^{18} \mathrm{O}$ and $\delta^{13} \mathrm{C}$ of bulk carbonate, and Potamogeton radiocarbon ages (Fig. 2); these correlations also agree with those based on fine-scale visual stratigraphy of Potamogeton layers. Charcoal is scarce in the lower half of the cores and we obtained only one radiocarbon measurement from these depths (Table 2). This date (UCIT 3388) was measured using charcoal and terrestrial fly fragments from a $20-\mathrm{cm}$ length of sediment near the bottom of core $2 \mathrm{~A}$.

Due to the very small size of these charcoal samples (e.g., 100 to $200 \mu \mathrm{g}$ of carbon), we measured the $\delta^{13} \mathrm{C}$ value of only one sample. This value $(-24.1 \%)$ is distinct from the $\delta^{13} \mathrm{C}$ value of Potamogeton, the primary aquatic plant $(\sim-10 \%)$, but is close to values obtained for modern steppe plants surrounding the lake $(\sim-25$ to $-27 \%)$. We conclude that steppe plants are the likely source of this charcoal.

We calculated calendar ages of all radiocarbon dates using the CALIB radiocarbon calibration program v. 4.3 and the calibration dataset of Stuiver et al. (1998). Four of the six charcoal dates are not statistically different from the ages of Potamogeton from the same depth. The remaining two charcoal samples, AA44634 and UCIT3388, are younger than Potamogeton samples from the same depth (Table 2, Fig. 2).

Table 1

Radiocarbon measurements of living Potamogeton and surface sediments

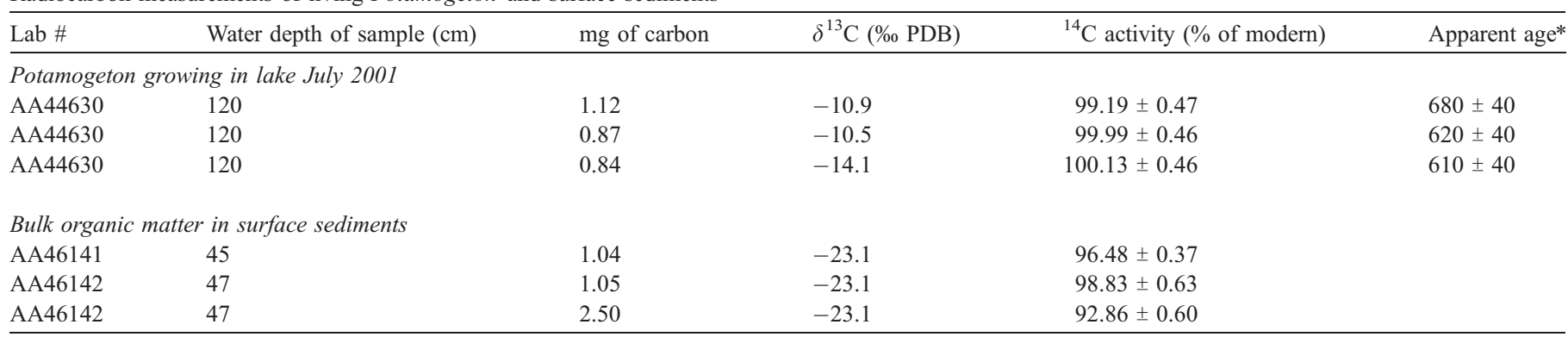

* Apparent age calculated using a modern ${ }^{14} \mathrm{C}$ activity of $108 \%$ (2001 conditions). 
Table 2

Radiocarbon dates from sediment cores

\begin{tabular}{|c|c|c|c|c|c|c|}
\hline $\mathrm{Lab} \#$ & Core & Composite depth $(\mathrm{cm})$ & $\mathrm{mg}$ of carbon & $\delta^{13} \mathrm{C}(\% \text { PDB })^{*}$ & ${ }^{14} \mathrm{C}$ age & $\begin{array}{l}\text { Calendar age } \\
\text { (median with } 2 \sigma \text { error range) }\end{array}$ \\
\hline \multicolumn{7}{|c|}{ Charcoal samples } \\
\hline AA50259 & $3 \mathrm{~A}$ & $2-4$ & 0.10 & N/A & $3600 \pm 70$ & $4090(3890) 3690$ \\
\hline AA44634 & $2 \mathrm{~A}, 3 \mathrm{~A}$ & $8-10,11-13$ & 0.19 & N/A & $3480 \pm 90$ & $3980(3790) 3480$ \\
\hline AA44636 & $2 \mathrm{~A}, 3 \mathrm{~A}$ & $22-24,20.5-22$ & 0.20 & -24.1 & $5090 \pm 80$ & $6160(5890) 5610$ \\
\hline AA44638 & $2 \mathrm{~A}, 3 \mathrm{~A}$ & $27-29,27-29$ & 0.15 & N/A & $5710 \pm 200$ & $6990(6490) 6000$ \\
\hline AA44640 & $2 \mathrm{~A}, 3 \mathrm{~A}$ & $38-40,39-41$ & 0.16 & N/A & $6640 \pm 340$ & $8160(7540) 6760$ \\
\hline UCIT338 $8^{\mathrm{a}}$ & $2 \mathrm{~A}$ & $67-87$ & $\sim 0.20$ & N/A & $7070 \pm 90$ & $8110(7900) 7680$ \\
\hline \multicolumn{7}{|c|}{ Potamogeton samples } \\
\hline AA41587 & $2 \mathrm{~A}$ & $0-1$ & 1.26 & -11.2 & $3810 \pm 60$ & $4410(4180) 3990$ \\
\hline AA41589 & $2 \mathrm{~A}$ & $5-6$ & 1.08 & -10.6 & $4160 \pm 50$ & $4830(4700) 4530$ \\
\hline AA42472 & $2 \mathrm{~A}$ & $9.5-10$ & 0.87 & -7.3 & $4250 \pm 40$ & $4860(4830) 4650$ \\
\hline AA46143 & $2 \mathrm{~A}$ & $12-12.5$ & 0.78 & -6.5 & $4200 \pm 50$ & $4850(4820) 4550$ \\
\hline AA46144 & $2 \mathrm{~A}$ & $16-16.5$ & 0.50 & -5.0 & $4430 \pm 50$ & $5290(5010) 4860$ \\
\hline AA47723 & $2 \mathrm{~A}$ & $18-18.5$ & 0.96 & -5.4 & $4640 \pm 40$ & $5470(5420) 5300$ \\
\hline AA46145 & $2 \mathrm{~A}$ & $20-20.5$ & 0.87 & -8.8 & $4990 \pm 60$ & $5990(5720) 5600$ \\
\hline AA41591 & $2 \mathrm{~A}$ & $23-23.5$ & 0.94 & -11.6 & $5510 \pm 50$ & $6410(6290) 6200$ \\
\hline AA42473 & $2 \mathrm{~A}$ & $28-29$ & 1.22 & -12.6 & $5660 \pm 50$ & $6620(6420) 6310$ \\
\hline AA42474 & $2 \mathrm{~A}$ & $39-39.5$ & 1.13 & -13.0 & $6180 \pm 50$ & 7250 (7090) 6910 \\
\hline AA47724 & $2 \mathrm{~A}$ & $47-47.5$ & 0.97 & -11.6 & $5980 \pm 60$ & $6980(6780) 6670$ \\
\hline AA46146 & $2 \mathrm{~A}$ & $55-55.5$ & 0.65 & -10.9 & $6430 \pm 70$ & $7460(7370) 7250$ \\
\hline AA47725 & $2 \mathrm{~A}$ & $58.5-58$ & 0.80 & -12.7 & $7240 \pm 60$ & $8180(8060) 7880$ \\
\hline AA47241 & $2 \mathrm{~A}$ & $63-63.5$ & 0.75 & -11.3 & $7210 \pm 60$ & 8170 (7990) 7880 \\
\hline AA47726 & $2 \mathrm{~A}$ & $68-68.5$ & 1.11 & -13.7 & $7740 \pm 60$ & $8630(8500) 8400$ \\
\hline AA46147 & $2 \mathrm{~A}$ & $73-73.5$ & 0.93 & -11.0 & $8050 \pm 50$ & $9080(9010) 8770$ \\
\hline AA47727 & $2 \mathrm{~A}$ & $80-80.5$ & 0.78 & -12.8 & $8570 \pm 60$ & $9680(9540) 9470$ \\
\hline AA46148 & $2 \mathrm{~A}$ & $87-87.5$ & 1.08 & -18.1 & $8800 \pm 60$ & $10,150(9850) 9560$ \\
\hline AA41588 & $3 \mathrm{~A}$ & $0-1$ & 1.15 & -9.1 & $3610 \pm 50$ & 4080 (3900) 3730 \\
\hline AA41590 & $3 \mathrm{~A}$ & $8-9$ & 0.99 & -11.3 & $3940 \pm 30$ & $4500(4410) 4290$ \\
\hline AA42475 & $3 \mathrm{~A}$ & $12.5-13$ & 1.01 & -11.3 & $4110 \pm 40$ & 4820 (4610) 4450 \\
\hline AA47729 & $3 \mathrm{~A}$ & $15.5-16$ & 1.17 & -6.7 & $4200 \pm 40$ & 4840 (4820) 4570 \\
\hline AA47730 & $3 \mathrm{~A}$ & $17.5-18$ & 1.06 & -7.8 & $4170 \pm 50$ & $4840(4720) 4530$ \\
\hline AA47240 & $3 \mathrm{~A}$ & $19.5-20.5$ & 1.19 & -10.2 & $4780 \pm 50$ & $5600(5510) 5330$ \\
\hline AA41592 & $3 \mathrm{~A}$ & $21.5-22$ & 0.94 & -10.9 & $5260 \pm 40$ & $6170(5990) 5920$ \\
\hline AA42476 & $3 \mathrm{~A}$ & $28-29$ & 1.01 & -10.8 & $5600 \pm 50$ & $6490(6370) 6290$ \\
\hline AA42477 & $3 \mathrm{~A}$ & $40.5-41$ & 0.76 & -10.8 & $6070 \pm 80$ & $7210(6900) 6690$ \\
\hline AA47728 & $3 \mathrm{~A}$ & $48-48.5$ & 1.10 & -12.2 & $6060 \pm 40$ & $6970(6820) 6800$ \\
\hline AA47242 & $3 \mathrm{~A}$ & $52.5-53.5$ & 1.36 & -10.4 & $6400 \pm 60$ & $7430(7320) 7210$ \\
\hline AA47731 & $3 \mathrm{~A}$ & $57-57.5$ & 0.78 & -11.9 & $6700 \pm 50$ & 7660 (7570) 7480 \\
\hline AA47732 & $3 \mathrm{~A}$ & $62-62.5$ & 0.86 & -11.0 & $7200 \pm 40$ & 8150 (7990) 7880 \\
\hline AA47243 & $3 \mathrm{~A}$ & $65.5-66.5$ & 0.69 & -11.5 & $6740 \pm 50$ & $7680(7600) 7510$ \\
\hline AA47733 & $3 \mathrm{~A}$ & $71-71.5$ & 0.93 & -13.9 & $7210 \pm 50$ & 8160 (7990) 7880 \\
\hline AA47734 & $3 \mathrm{~A}$ & $76-76.5$ & 0.86 & -12.2 & $7900 \pm 60$ & $9000(8670) 8540$ \\
\hline AA47735 & $3 \mathrm{~A}$ & $84-84.5$ & 0.64 & -13.7 & $8420 \pm 70$ & 9540 (9460) 9160 \\
\hline AA41585 & $4 \mathrm{~A}$ & $0-1$ & 0.94 & -12.2 & $3640 \pm 50$ & 4090 (3940) 3780 \\
\hline AA42466 & $4 \mathrm{~A}$ & $8.5-9$ & 1.04 & -11.4 & $3920 \pm 40$ & $4500(4410) 4240$ \\
\hline AA42467 & $4 \mathrm{~A}$ & $12-12.5$ & 1.12 & -10.2 & $4170 \pm 50$ & $4840(4720) 4530$ \\
\hline AA47719 & $4 \mathrm{~A}$ & $16-16.5$ & 0.95 & -6.9 & $4190 \pm 50$ & $4850(4750) 4530$ \\
\hline AA47720 & $4 \mathrm{~A}$ & $20-20.5$ & 0.88 & -11.8 & $5500 \pm 40$ & $6400(6290) 6200$ \\
\hline AA47991 & $4 \mathrm{~A}$ & $23-23.5$ & 1.33 & -10.8 & $5390 \pm 40$ & $6290(6200) 6000$ \\
\hline AA42468 & $4 \mathrm{~A}$ & $25-25.5$ & 1.09 & -11.5 & $5610 \pm 50$ & $6490(6360) 6290$ \\
\hline AA42469 & $4 \mathrm{~A}$ & $28.5-29$ & 1.22 & -12.3 & $5760 \pm 50$ & $6720(6550) 6410$ \\
\hline AA42470 & $4 \mathrm{~A}$ & $32-32.5$ & 1.21 & -11.6 & $5950 \pm 50$ & $6590(6770) 6660$ \\
\hline AA42471 & $4 \mathrm{~A}$ & $38.5-39$ & 1.10 & -11.3 & $6310 \pm 50$ & $7410(7250) 7030$ \\
\hline AA47244 & $4 \mathrm{~A}$ & $40.5-41$ & 1.02 & -9.6 & $6530 \pm 70$ & $7570(7430) 7280$ \\
\hline AA47245 & $4 \mathrm{~A}$ & $47-47.5$ & 1.00 & -12.5 & $6890 \pm 100$ & 7940 (7680) 7570 \\
\hline AA47721 & $4 \mathrm{~A}$ & $54-54.5$ & 0.86 & -15.6 & $6960 \pm 40$ & 7920 (7770) 7670 \\
\hline AA47722 & $4 \mathrm{~A}$ & $58-58.5$ & 0.84 & -12.6 & $7130 \pm 40$ & 8100 (7940) 7860 \\
\hline AA47246 & $4 \mathrm{~A}$ & $65-65.5$ & 0.98 & -11.4 & $6840 \pm 60$ & 7790 (7670) 7580 \\
\hline
\end{tabular}

${ }^{\text {a }}$ Sample also contained terrestrial fly fragments.

* Samples marked N/A have no $\delta^{13} \mathrm{C}$ measurements. 
The age of sample AA44634 is assumed to be inaccurate because it does not agree with other charcoal dates and would require an age reversal in the sediments. Sample UCIT3388 spans a $20-\mathrm{cm}$ interval, but most of the material is derived from the upper several centimeters of this interval. The age of UCIT3388 and the age of Potamogeton from this smaller interval are not significantly different.

From this, we conclude that the hard-water effect was small $(<600-700 \mathrm{yr})$ and relatively constant through time. We base the age model for these cores on the four consistent charcoal dates and the Potamogeton dates, which are fit best by three lines with inflection points at $20 \mathrm{~cm}$ and $28 \mathrm{~cm}$ (Fig. 2). This fit implies a period of lower sedimentation rate between 5000 and $6000 \mathrm{cal}$ yr B.P. Potamogeton dates also indicate that sedimentation rates were lower in cores $3 \mathrm{~A}$ and $4 \mathrm{~A}$ than in core $2 \mathrm{~A}$ during this interval. Fine-scale correlation of geochemical time-series from these cores suggest that cores $3 \mathrm{~A}$ and $4 \mathrm{~A}$ lack a $6-\mathrm{cm}$ length of sediment present in core 2A (Fig. 2). The significance of this will be discussed in later sections. Similar gaps also seem to occur from 48 to $56.5 \mathrm{~cm}$ in core $4 \mathrm{~A}$ and from 61.5 to $68.5 \mathrm{~cm}$ in core 2A (Fig. 2). We chose not to add inflection points to the age model at these intervals because the gaps occur in only one core and radiocarbon dates from the other cores do not show a change in sedimentation rate.

\section{Geochemical measurements}

We measured \% carbonate and the $\delta^{18} \mathrm{O}$ and $\delta^{13} \mathrm{C}$ of bulk carbonate for all three cores for the purpose of core correlation. For core $3 \mathrm{~A}$, we measured additional variables for a more complete record of past variations in monsoon strength. This section describes our measurement methods and the next section discusses how the sediment geochemistry reflects past environmental and climatic change.

We measured the percent by weight of total carbon (TC) and inorganic carbon (IC) in bulk sediment at $0.5-\mathrm{cm}$ intervals using a UIC Coulometrics model 5011 coulometer in the University of Arizona (UA) Geosciences Department. Reagentgrade $\mathrm{CaCO}_{3}$ standards indicate measurement errors less than $0.02 \%$ by weight. Percent total organic carbon (TOC) was calculated as the difference between TC and IC. We calculated the percent of carbonate $\left(\mathrm{CaCO}_{3}\right)$ by multiplying IC by 8.3 , which is a scaling factor that accounts for the atomic mass of calcium and oxygen.

We measured the $\delta^{18} \mathrm{O}$ and $\delta^{13} \mathrm{C}$ of bulk carbonate and of carbonate encrustations that precipitated inorganically around the stems of Potamogeton. Measurements were made in the UA Geosciences Department using a Micromass Optima mass spectrometer with automated common acid bath carbonate preparation device. Analytical precision, based on replicate measurements of a carbonate standard, was $\pm 0.02 \% 0 \delta^{13} \mathrm{C}$ and $\pm 0.07 \%$ o $\delta^{18} \mathrm{O}$. In addition, we measured the $\delta^{18} \mathrm{O}$ of surface water and precipitation samples from 1995 and 2001 on, respectively, a VG SIRA mass spectrometer with $\mathrm{CO}_{2}$ equilibration automated preparation device at the Institute for Arctic and Alpine Research at the University of Colorado and a Finnigan Delta $\mathrm{S}$ mass spectrometer with $\mathrm{CO}_{2}$ equilibration automated preparation device at UA. The analytical precision is $\pm 0.05 \%$ o $\delta \delta^{18} \mathrm{O}$.

The carbon-to-nitrogen ratio $(\mathrm{C} / \mathrm{N})$ and $\delta^{13} \mathrm{C}$ were measured for several modern plant samples and also for bulk organic matter in core sediments at $1-\mathrm{cm}$ intervals. To remove inorganic carbon from core sediments, we treated all samples with $8 \%$ sulfurous acid using the technique of Verardo et al. (1990). This method has several advantages over other techniques for carbonate-rich sediments: (1) excess acid is released as $\mathrm{SO}_{2}$ gas, which eliminates the need for multiple rinsing steps during which sample can be lost, (2) samples are completely decalcified, and (3) water is not retained by hygroscopic salts (Verardo et al., 1990). Samples were analyzed on a Finnigan Delta Plus with Elemental Analyzer interface at UA. The standard deviations of replicate analyses of an acetanilide standard were $\pm 0.12 \mathrm{C} / \mathrm{N}$ and $\pm 0.04 \%{ }_{0} \delta^{13} \mathrm{C}$.

We measured the percent by volume of dolomite in the nonorganic fraction of bulk sediment using X-ray diffraction methods. We removed organic matter from samples by treatment with $5 \% \mathrm{NaOCl}$ (commercial Clorox) for 3 days. Previous studies indicate that this treatment causes no dissolution of carbonate minerals and is also the most effective for removing organic material (Gaffey and Bronnimann, 1993). Our analysis of several samples before and after this treatment verifies that the treatment did not alter any mineral diffraction patterns.

We generated diffractograms for $50 \mathrm{mg}$ of each sample using a Siemens D-500 X-ray diffractometer with $\mathrm{CuK} \alpha$ radiation at UA. We calculated the area of dolomite's major peak by multiplying the peak height and the peak width at halfheight. This calculation approximates the actual peak area well and eliminates problems associated with overlapping peaks (Moore, 1989). To calibrate the relationship between XRD peak area and mineral percent, we analyzed artificial mixtures with known amounts of dolomite. By comparing known and measured values, we estimate that our calculated values are accurate to within $\pm 1 \%$.

\section{Proxy interpretations}

\section{Carbonate and organic carbon}

The percents of carbonate and organic carbon are negatively correlated and reflect alternations between Potamogeton-rich layers and carbonate-rich layers (Fig. 3). The carbonate in this core consists primarily of calcitic micrite and aragonitic encrustations that formed on the stems of the aquatic macrophyte Potamogeton, but also contains small quantities of gastropods, ostracods, and detrital grains. Potamogeton fragments in the core are several centimeters long and were deposited horizontally in densely-packed layers. In the lake today, Potamogeton grows in water depths between 40 and 110 $\mathrm{cm}$ (Fig. 4). Water depth has a strong effect on the distribution of aquatic macrophytes, affecting macrophytes by decreased light availability in deep water and by mechanical damage by ice and exposure in shallow water (Blindow et al., 1993). The carbonate-rich intervals lacking Potamogeton more likely formed in waters $>110 \mathrm{~cm}$, not $<40 \mathrm{~cm}$. If the lake were only 

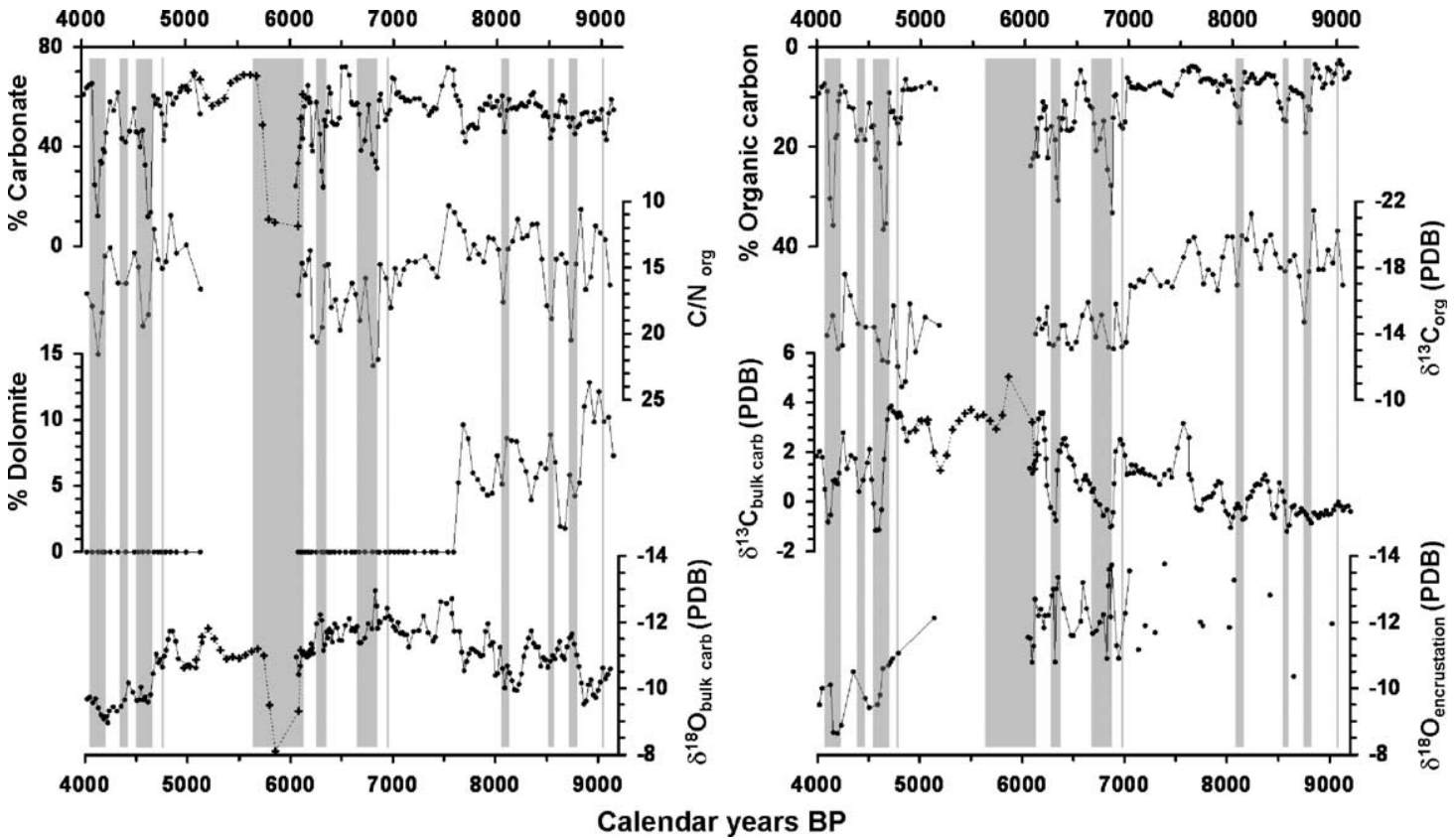

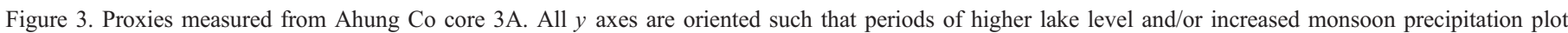

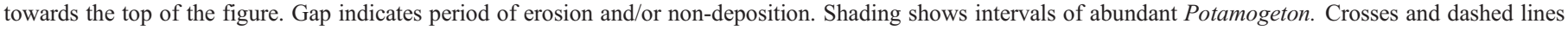
show measurements from core $2 \mathrm{~A}$ that span the gap in core $3 \mathrm{~A}$.

$40 \mathrm{~cm}$ deep, it would be closed. The presence of Planorbiid gastropods that require freshwater (Baker, 1945) and $\delta^{18} \mathrm{O}$ values indicative of overflowing conditions (see below) argue against this possibility.

\section{$C / N$ and $\delta^{13} C$ organic}

Variations in the $\mathrm{C} / \mathrm{N}$ ratio and $\delta^{13} \mathrm{C}$ of bulk organic matter reflect changes in the relative amounts of lacustrine algae, which are the dominant organic material in carbonate-rich intervals, and Potamogeton. Intervals of low (high) $\mathrm{C} / \mathrm{N}$ and low (high) $\delta^{13} \mathrm{C}$ are dominated by algae (Potamogeton) (Fig. $5)$. Terrestrial plant material, with the exception of small quantities of charcoal, is not present in the sediments. While the $\mathrm{C} / \mathrm{N}$ ratio shows fine-scale variations corresponding to individual Potamogeton-rich intervals, $\delta^{13} \mathrm{C}$ values only record the major increase in Potamogeton around 7000 cal yr B.P. (Fig. 3). This might be explained by the competing influence of large changes in the $\delta^{13} \mathrm{C}$ of lake dissolved inorganic carbon (DIC) during these short-scale fluctuations (see below).

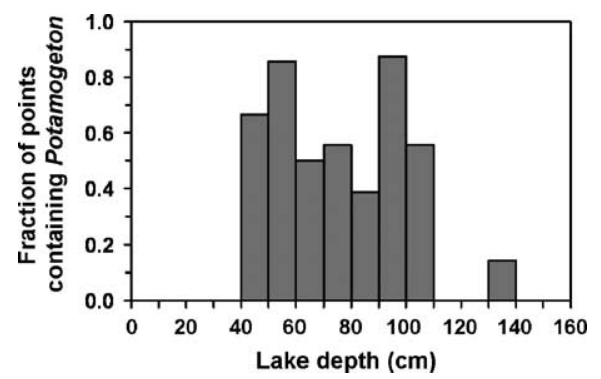

Figure 4. Occurrence of Potamogeton with depth in Ahung Co derived from observations during July 2001 of the presence or absence of Potamogeton at 110 points distributed throughout the lake.

\section{Dolomite}

There are several possible sources for dolomite in lake sediments. These include: (1) direct precipitation from saline lake water, (2) precipitation as a cement during diagenesis of lake sediments, (3) loess deposition, and (4) detrital dolomite transported by water from bedrock sources in the drainage basin. The last possibility is the simplest explanation for the presence of dolomite, since near-shore surface sediments contain pebbles of detrital dolomite. It is unlikely that loess is the source because loess in Tibet typically consists mostly of quartz and clay minerals $(50-90 \%)$, with small $(0-3 \%)$ amounts of dolomite (Pewe et al., 1995).

\section{$\delta^{13} C$ carbonate}

Fluctuations in $\delta^{13} \mathrm{C}$ values of bulk carbonate correspond with the amount of Potamogeton preserved in the sediment

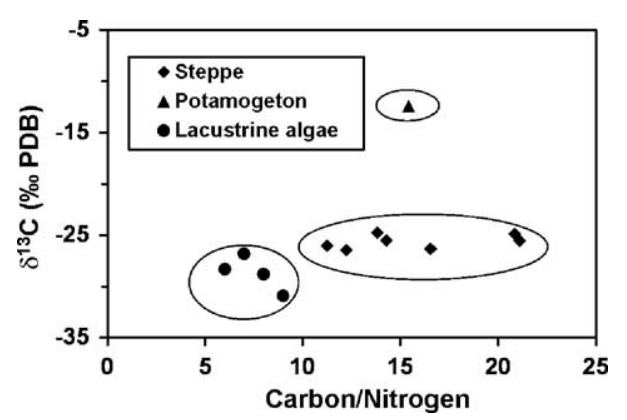

Figure 5. $\mathrm{C} / \mathrm{N}$ and $\delta^{13} \mathrm{C}$ values for three categories of organic matter. Steppe plants and Potamogeton were collected at Ahung Co during July 2001. Measurements for lacustrine algae were collected from Asian and North American lakes (Meyers, 1994). 
(Fig. 3). This might be explained by the fact that Potamogeton discriminates less against ${ }^{13} \mathrm{C}$ during photosynthesis than do lacustrine algae, causing lake DIC to have a more negative $\delta{ }^{13} \mathrm{C}$ value when photosynthesis is dominated by Potamogeton. The isotopic compositions of Potamogeton and lacustrine algae are different enough (about 10\%o) to make this a potentially large effect.

\section{$\delta^{18} \mathrm{O}$ carbonate}

Variations in the $\delta^{18} \mathrm{O}$ of bulk carbonate may reflect changes in one or more of the following factors: (1) lake temperature at the time of carbonate precipitation, (2) the relative amounts of aragonite and calcite, (3) the relative amount of detrital carbonate, (4) the $\delta^{18} \mathrm{O}$ values of lake water. It is unlikely that changes in $\delta^{18} \mathrm{O}$ values were caused primarily by changes in lake temperature because lake temperature must change $4.5^{\circ} \mathrm{C}$ to yield a $1 \%$ change in $\delta^{18} \mathrm{O}$ value (Grossman and $\left.\mathrm{Ku}, 1986\right)$. Similarly, variations in the amount of aragonite, which is enriched in ${ }^{18} \mathrm{O}$ relative to calcite formed under the same conditions by about 0.6 to $0.9 \%$ (e.g., Grossman and $\mathrm{Ku}, 1986$ ), are too small to explain the $\delta^{18} \mathrm{O}$ variations (not shown).

Detrital dolomite is present in the bottom third of the core. Fluctuations in the amount of dolomite are strongly positively correlated to variations in $\delta^{18} \mathrm{O}$ (Fig. 6). The relationship between $\%$ dolomite and carbonate $\delta^{13} \mathrm{C}$ is not as strong (not shown). This is probably because the $\delta^{13} \mathrm{C}$ values of the dolomite, a marine carbonate ( $\sim 0 \%$ PDB), are similar to the $\delta{ }^{13} \mathrm{C}$ values of the lake carbonate ( -2 to $4 \%$ o PB).

Using the relationship between the $\%$ dolomite and $\delta^{18} \mathrm{O}$ (Fig. 6), we estimate that the $\delta^{18} \mathrm{O}$ value of the dolomite is $4.8 \%$ PDB. Ideally, this value would be obtained from dolomite collected from the basin. One dolomite sample we collected from near-shore surface sediments yields a $\delta^{18} \mathrm{O}$

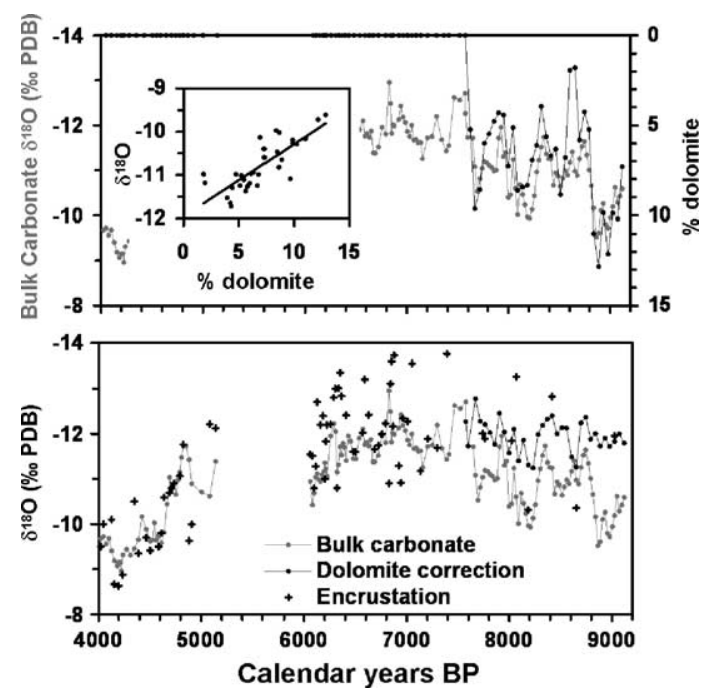

Figure 6. Correction of bulk carbonate $\delta^{18} \mathrm{O}$ measurements in core $3 \mathrm{~A}$ for the presence of dolomite. Top: Time-series of bulk carbonate $\delta^{18} \mathrm{O}$ (gray) and $\%$ dolomite (black) and their correlation. Bottom: Measured $\delta^{18} \mathrm{O}$ of bulk carbonate (gray), corrected $\delta^{18} \mathrm{O}$ of bulk carbonate (black dots) and measured $\delta^{18} \mathrm{O}$ of Potamogeton encrustations (black crosses). value of $-5.4 \%$ o PDB. The difference in these values might be explained by our inability to completely remove lacustrine carbonate precipitates from the dolomite sample. In the absence of a trustworthy value from a dolomite sample, we used our estimated value $(4.8 \%$ ) and a mass balance calculation to correct for the presence of dolomite. The resulting curve agrees better with most of the $\delta^{18} \mathrm{O}$ measurements made from Potamogeton encrustations, which we measured whenever possible to eliminate the contribution of detrital calcite (Fig. 6). The $\delta^{18} \mathrm{O}$ values of these two materials are similar, although values from bulk carbonate are less variable because they reflect conditions averaged over $\sim 50 \mathrm{yr}$ as opposed to several months.

In the upper two thirds of the core, detrital dolomite is absent and the trend of the $\delta^{18} \mathrm{O}$ of bulk carbonate agrees with the $\delta^{18} \mathrm{O}$ of authigenic encrustations (Fig. 6). This trend must be caused by changes in the $\delta^{18} \mathrm{O}$ of lake water, which is a function of (1) the $\delta^{18} \mathrm{O}$ of precipitation and (2) the residence time of water in the lake and/or catchment. Today, both factors are dependent on the amount of monsoon precipitation (Morrill, 2004). First, summer monsoon precipitation, which is derived from the Indian and/or Pacific oceans and falls from large frontal systems, is generally between -15 and $-20 \%$, as opposed to precipitation from local convective systems, which is derived from continental water sources and has values typically between -5 and $-10 \%$. This is shown by our limited measurements in 2001 (Table 3) as well as more extensive sampling by Tian et al. (2001) at Nagqu. The low $\delta{ }^{18} \mathrm{O}$ values of monsoon precipitation are due to progressive rain-out of the monsoon air masses as they move inland (Araguas-Araguas et al., 1998). Second, as discussed previously, Morrill (2004) showed that recent water-balance fluctuations in Ahung Co are caused primarily by variations in monsoon precipitation.

The effects of monsoon precipitation on the $\delta^{18} \mathrm{O}$ of lake water are especially clear today. In July 1995, after several years of below-average monsoon precipitation, the lake was closed and the $\delta^{18} \mathrm{O}$ of lake water was $+2.3 \%$ (Table 3 ). By July 2001, several years of above-average monsoon rainfall raised the lake level to overflowing and $\delta^{18} \mathrm{O}$ fell to $-9.5 \%$ SMOW (Table 3).

Assuming summer water temperatures between $10^{\circ}$ and $20^{\circ} \mathrm{C}$, conditions observed in July 2001, we calculate that sediment carbonates must have precipitated from water between -9 and $-14 \%$ SMOW. Based on this and the $\delta{ }^{18} \mathrm{O}$ of lake water in 1995 and 2001, we conclude that the lake was not closed for any extended period of time during the period of sediment deposition.

\section{Inferred lake-level and monsoon history}

We used principal component analysis (PCA) to identify the major transitions and fluctuations that are common to our expanded suite of proxies from core $3 \mathrm{~A}$. For the PCA we used the time-series shown in Figure 3, with three exceptions. First, we excluded \% organic carbon because it is strongly anticorrelated with $\%$ carbonate $\left(r^{2}=0.58\right)$ due 
Table 3

$\delta^{18} \mathrm{O}$ values of lake water and rainfall

\begin{tabular}{lcc}
\hline Sample & Collection date & $\delta^{18}$ O (\%o VSMOW) \\
\hline Ahung Co lake water & & \\
Center of lake & 23 July 1995 & 2.27 \\
Center of lake & 23 July 1995 & 2.27 \\
Center of lake & 23 July 1995 & 2.31 \\
Shore of lake & 9 July 2001 & -9.85 \\
Outflow & 12 July 2001 & -9.62 \\
Shore of lake & 12 July 2001 & -9.10 \\
Center of lake & 12 July 2001 & -9.30 \\
& & \\
Precipitation & & \\
Convective storm, Nagqu & 8 July 2001 & -2.91 \\
Frontal storm, Ahung Co & 10 July 2001 & -18.86 \\
Frontal storm, Nagqu & 10 July 2001 & -16.38 \\
Frontal storm, Nagqu & 11 July 2001 & -17.20 \\
\hline
\end{tabular}

to dilution. Excluding \% carbonate instead, or excluding any of the other time-series, does not change the results (not shown). Second, we used the $\delta^{18} \mathrm{O}$ time-series corrected for the presence of dolomite (Fig. 6). Last, we excluded the low-resolution time-series of $\delta^{18} \mathrm{O}$ values measured from encrustations.

Using the graphical test described by Wilks (1995), we determined that the first three principal components contain important information. The first PC shows a trend with greatest change between 7000 and 7500 cal yr B.P. (Fig. 7). The second PC shows multi-century oscillations that correspond to alternations between Potamogeton-rich and carbonate-rich layers. Phases of these oscillations that align with Potamogeton-rich intervals are labeled $\mathrm{A}-\mathrm{G}$ in Figure 7. The third PC shows a step change at $\sim 4700$ cal yr B.P. Climatic interpretation of these events is as follows:

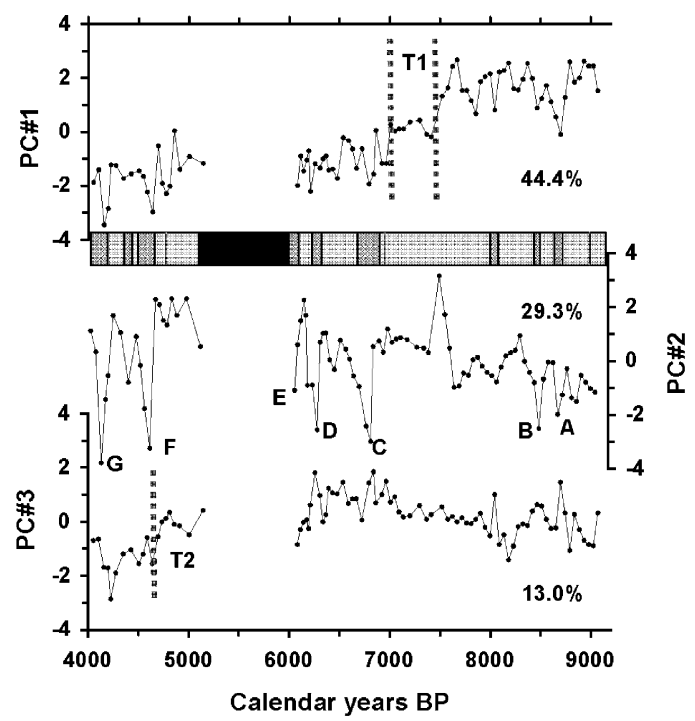

Figure 7. First three principal components calculated for six proxies from core 3A. All y axes are oriented such that periods of higher lake level and/or increased monsoon precipitation plot towards the top of the figure. Percent of total variance in the time-series explained by the principal component shown on right. Lithologic column shows intervals of abundant Potamogeton, as in Figure 2. T1 and T2 indicate periods of rapid change. Letters A-G identify times of peak dryness during multi-century oscillations.
Transition 1 (7000-7500 cal yr B.P.)

The first PC is significantly correlated with five of the six proxies used in the PCA (Table 4). Two of these proxies, C/N and $\delta{ }^{13} \mathrm{C}$ organic, indicate that the amount of Potamogeton increased sharply between 7000 and 7500 cal yr B.P. This agrees with the $\%$ carbonate and $\%$ organic carbon time-series, which show the first significant growth of Potamogeton at the core site at this time (Fig. 3). The increase in Potamogeton was likely due to a decrease in lake level to depths more suitable for its growth. We emphasize, however, that Potamogeton growth responds non-linearly to lake depth (Fig. 4). Thus, a gradual decrease in lake level could produce an abrupt increase in Potamogeton abundance.

Of the other proxies, detrital dolomite decreased abruptly to below the detection limits $(1-2 \%)$ of our XRD analysis around $7500 \mathrm{cal}$ yr B.P. This might indicate a reduction in runoff from the drainage basin. In addition, $\delta^{18} \mathrm{O}$ values declined following this transition, reflecting increased residence time and/or less monsoon precipitation. The correlation between the first PC and the $\delta^{13} \mathrm{C}$ of bulk carbonate is more difficult to interpret because of possible effects of dolomite deposition on $\delta^{13} \mathrm{C}$ values before 7500 cal yr B.P. Overall, we argue that the first $\mathrm{PC}$ reflects a decrease in lake level and monsoon precipitation through the Holocene, with the greatest change occurring between 7000 and 7500 cal yr B.P. following an early Holocene monsoon maximum.

\section{Multi-century oscillations}

Alternations between Potamogeton-rich intervals and intervals dominated by carbonate and algal remains are clearly shown by the second PC (Fig. 7), though they are muted before $7000 \mathrm{cal}$ yr B.P. when the lake was perhaps too deep at the core site for significant Potamogeton growth. Similar alternations occur in shallow lakes in many regions of the world (e.g., Blindow et al., 1993; Engel and Nichols, 1994; Coops and Doef, 1996). These states might represent two stable equilibria in shallow lakes (e.g., Scheffer et al., 1993). In one state, lacustrine algae dominate. They form blooms in the surface water and reduce the transparency of lake water, which prevents macrophyte growth. In the other state, transparency is increased and aquatic macrophytes, such as Potamogeton, dominate. Macrophytes suppress algal growth by harboring zooplankton that graze phytoplankton and by releasing sub-

Table 4

Correlation coefficients of proxy time-series and principal components

\begin{tabular}{lrrr}
\hline Proxy & PC \#1 & PC \#2 & PC \#3 \\
\hline \% Carbonate & 0.35 & $\mathbf{0 . 7 9}$ & 0.24 \\
$\mathrm{C} / \mathrm{N}$ ratio & $-\mathbf{0 . 6 4}$ & $-\mathbf{0 . 5 8}$ & 0.40 \\
$\delta^{13} \mathrm{C}_{\text {organic }}$ & $-\mathbf{0 . 9 3}$ & 0.00 & 0.20 \\
$\%$ Dolomite & $\mathbf{0 . 8 0}$ & -0.36 & 0.14 \\
$\delta^{13} \mathrm{C}_{\text {carbonate }}$ & $\mathbf{0 . 4 5}$ & $\mathbf{0 . 8 1}$ & 0.00 \\
$\delta^{18} \mathrm{O}_{\text {carbonate }}$ & $\mathbf{- 0 . 6 5}$ & 0.00 & $-\mathbf{0 . 7 1}$ \\
\hline
\end{tabular}

Correlation coefficients statistically significant at the $99.9 \%$ confidence level are in bold. 
stances toxic to the algae (Scheffer et al., 1993). Macrophytes also improve water clarity by reducing resuspension of bottom material. Environmental disturbances cause the system to shift between the two states. These disturbances include changes in lake level, sediment or nutrient loading, ice thickness, or wind mixing (Blindow et al., 1993; Coops and Doef, 1996; Engel and Nichols, 1994).

In the case of Ahung Co, we argue for two reasons that Potamogeton-rich intervals formed when the monsoon was weaker and water levels were lower. First, Potamogeton growth in Ahung Co is clearly dependent on water depth (Fig. 4). Second, we find some correspondence between Potamogeton-rich intervals and periods of more enriched $\delta^{18} \mathrm{O}$ measured from encrustations (Fig. 3). This extends to core $2 \mathrm{~A}$, as well, where enriched $\delta^{18} \mathrm{O}$ values between 5800 and $6100 \mathrm{cal}$ yr B.P. correspond with an interval of particularly abundant Potamogeton (Fig. 3).

Low $\delta^{18} \mathrm{O}$ values measured from the core indicate that Ahung Co overflowed throughout the period of sediment deposition. This does not mean, however, that lake levels must have remained steady relative to the sill depth. Today, during periods of overflow, lake level has risen at least $40 \mathrm{~cm}$ above the elevation of the sill (Morrill, 2004). Lake level fluctuations of this size are large enough to cause variations in the amount of Potamogeton.

\section{Transition 2 (4700 cal yr B.P.)}

The third PC shows a step change that is significantly correlated to a shift in the $\delta^{18} \mathrm{O}$ record to less negative values (Table 4, Fig. 3). We infer that monsoon precipitation decreased and the residence time of water in the lake increased at this time. The shift in $\delta^{18} \mathrm{O}$ values is also apparent in measurements using Potamogeton encrustations (Fig. 3), indicating that it reflects changes in the $\delta^{18} \mathrm{O}$ of DIC rather than detrital influence. Unlike Transition 1, Potamogeton did not become more abundant at this time. This might be explained by the non-linear response of this proxy to lake depth (Fig. 4).

\section{Late Holocene (<4000 cal yr B.P.)}

The cores do not contain sediment from the last $\sim 4000$ calendar years. We argue that the lake was too shallow to accumulate sediments during some or all of this time. When lake level falls below a critical depth in very shallow lakes, wind mixing increases, sediment will cease to be deposited and previously deposited sediments can be eroded (Verschuren, 1999; Douglas and Rippey, 2000). Desiccation of the lake and deflation of exposed sediments are also possible, but we have found no evidence for this, such as unconformities or changes in sediment texture. It is more probable that the lake became shallower but did not completely desiccate. The possibility of sediment erosion makes it impossible to say at what times the lake was too shallow for sediment accumulation. A similar drop in lake level can explain changes between 5000 and 6000 cal yr B.P., when the sedimentation rate of core $2 \mathrm{~A}$ decreased and there was a period of erosion and/or non-deposition in cores $3 \mathrm{~A}$ and $4 \mathrm{~A}$. The large increase in $\delta^{18} \mathrm{O}$ values in core $2 \mathrm{~A}$ at the start of this interval supports this interpretation. Under this scenario, the more complete sediment record of core $2 \mathrm{~A}$ might be explained by spatial variations in mixing and sediment focusing on the bottom of the lake.

Sediment infilling through the Holocene contributed to low lake levels during the late Holocene, but it cannot be the sole explanation. Infilling alone would lead to a decrease in lake volume, a decrease in lake-water residence time and decreased $\delta^{18} \mathrm{O}$ values. Instead, we find an increase in $\delta^{18} \mathrm{O}$ values through the Holocene (Fig. 6), consistent with declining monsoon precipitation.

We did not recover the top 1 or $2 \mathrm{~cm}$ of surface sediments during coring. Bulk organic matter in surface sediments in shallower parts of the lake has ${ }^{14} \mathrm{C}$ activities between $\sim 93$ and $99 \%$ (Table 1). The $\delta^{13} \mathrm{C}$ values of these samples and visual examination of the sediments indicate that most of the organic matter is lacustrine algae. It is difficult to assign an exact age to these sediments because of large recent variations in atmospheric ${ }^{14} \mathrm{C}$ due to bomb testing. It is clear, however, that these sediments are not $\sim 4000$ yr old. Assuming a hard-water correction similar to that measured in modern Potamogeton, these samples yield ${ }^{14} \mathrm{C}$ activities between $\sim 100$ and $107 \%$, suggesting they contain a mixture of bomb and pre-bomb radiocarbon. Therefore, during the 20th century and possibly earlier, sediment accumulated in the lake, probably due to increased lake level and monsoon precipitation.

\section{Discussion}

The sediment record from Ahung Co indicates that monsoon precipitation decreased through the late and middle Holocene following maximum values before $7500 \mathrm{cal}$ yr B.P. Superimposed on this trend are two relatively rapid decreases in monsoon rainfall at 7000-7500 and $4700 \mathrm{cal}$ yr B.P. and several wet-dry oscillations with a median spacing of $\sim 500$ yr (range: 200 to $1650 \mathrm{yr}$ ). At one or more times after 4000 cal yr B.P., the lake probably became too shallow for sediment deposition and increased wind mixing caused sediment erosion and/or resuspension. Similar conditions might have existed between 5000 and $6000 \mathrm{cal}$ yr B.P. when the sedimentation rate of core $2 \mathrm{~A}$ decreased and there was a period of erosion and/or non-deposition in cores $3 \mathrm{~A}$ and $4 \mathrm{~A}$. Surface sediments in the lake accumulated during the 20th century and possibly earlier. The age of these recent sediments is not well constrained, but we speculate that they correlate to an increase in monsoon strength during the past $400 \mathrm{yr}$ inferred by Anderson et al. (2002) for the Indian Ocean.

This is the first water-balance record from Tibet to have an age model based on terrestrial material. Our results illustrate a problem in using core-top dates from aquatic plant material to determine the hard-water effect, a method used for other Tibetan lakes. It is nearly impossible to distinguish between a sedimentary gap at the top of the core due to low lake level and 
a large hard-water effect. Measurements of ${ }^{14} \mathrm{C}$ activity in the modern lake can indicate the expected hard-water effect. However, changes in the hard-water effect through time must also be considered.

A decrease in monsoon strength through the Holocene is apparent in other records, including those from Sumxi Co, Bangong Co, the Arabian Sea, Oman and elsewhere (Fig. 8; Gasse et al., 1991, 1996; Overpeck et al., 1996; Liu et al., 1998; Fleitmann et al., 2003). This is expected given declining summer insolation through the Holocene. During the summer,
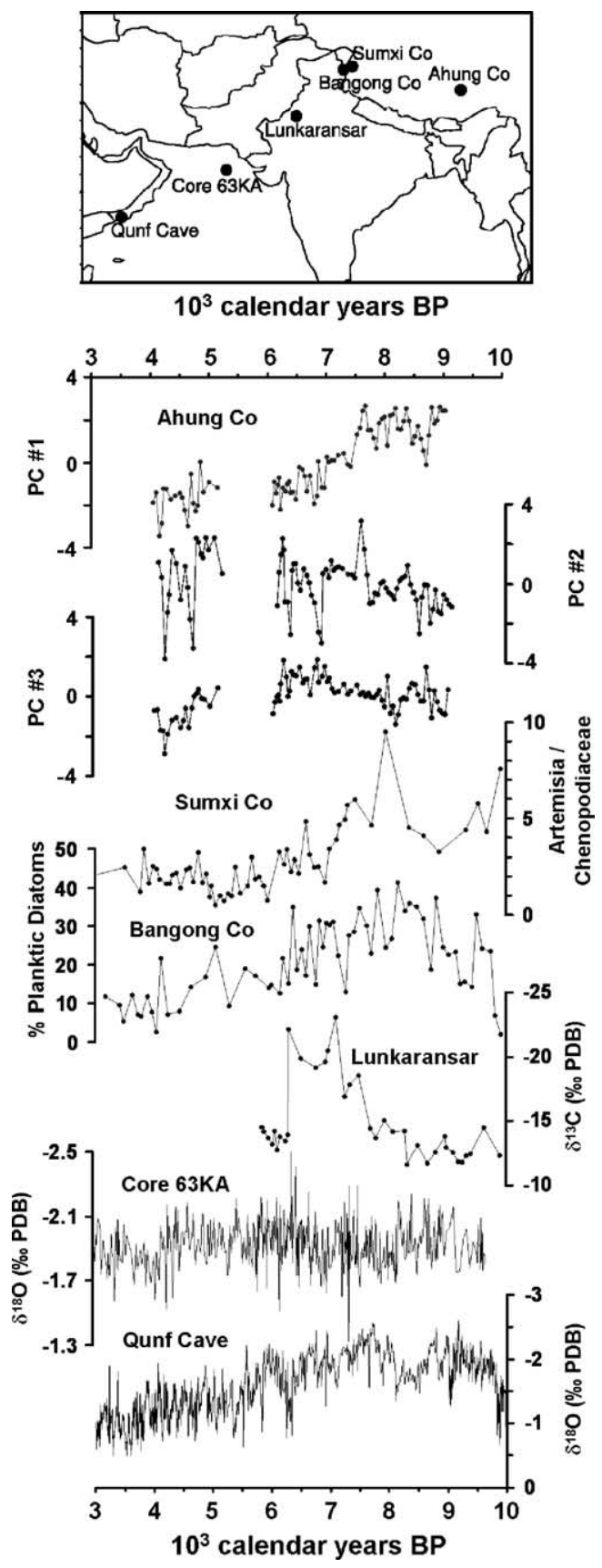

Figure 8. High-resolution records of southwest Asian monsoon. All $y$ axes are oriented such that periods of increased monsoon precipitation plot towards the top of the figure. Data from: Ahung Co, this study; Sumxi Co, Gasse et al. (1991); Bangong Co, Gasse et al. (1996); Lunkaransar, Enzel et al. (1999); Core 63KA, Staubwasser et al. (2002); Qunf Cave, Fleitmann et al. (2003). temperatures over Asia increase more than temperatures over the Indian Ocean due to the higher specific heat of water. This results in a temperature gradient that fuels the monsoon circulation. When summer insolation is lower, the temperature contrast between land and ocean is less pronounced and the monsoon circulation is weaker.

Rapid decreases in monsoon precipitation, such as those we inferred for 7000-7500 and 4700 cal yr B.P., are less consistent among nearby records (Fig. 8). This could be the result of (1) regional differences in monsoon history, (2) the influence of climatic variables other than monsoon precipitation, (3) local environmental changes such as neotectonics or changes in sill elevation, and/or (4) a non-linear response of proxies to environmental change, causing abrupt shifts in the proxies that do not correspond to an abrupt climate change. We argue for several reasons that the two transitions we documented at Ahung Co reflect changes in monsoon precipitation. First, a synthesis of 36 previously published records from across the Asian monsoon region showed an abrupt weakening in monsoon strength at 4500-5000 cal yr B.P. (Morrill et al., 2003). Second, some records from southwest Asia, including Sumxi Co, Bangong Co, and Qunf Cave show a first decrease in monsoon strength at $\sim 7000$ cal yr B.P., following the early Holocene maximum (Fig. 8). Short events like the wet-dry oscillations observed at Ahung Co are difficult to compare between records due to coarse resolution and dating uncertainties. As more highresolution records are published, we will be able to determine whether this century-scale variability is spatially coherent.

The causes of past monsoon variations are under debate. Possibilities include: changes in solar irradiance, temperature variations in the North Atlantic, and changes in the intensity and frequency of El Niño events (see review in Morrill et al., 2003). For many records, including Ahung Co, it is difficult to make a compelling case for any one of these factors controlling precipitation. Noise and dating uncertainties in both monsoon records and forcing time-series impede comparisons. It is also possible, and perhaps likely given the complexity of the climate system, that there are multiple causes that interact with one another.

\section{Conclusions}

- The sediment record from Ahung Co shows two abrupt declines in monsoon precipitation at 7000-7500 and 4700 cal yr B.P. In some records from southwest Asia, the first decrease in monsoon precipitation following the early Holocene monsoon maximum occurs at about 7000 cal yr B.P. The event at 4700 cal yr B.P. corresponds to a widespread, abrupt weakening of the Asian monsoon (Morrill et al., 2003).

- There were several $(\sim 7)$ multi-century fluctuations in Ahung Co between states dominated by aquatic macrophytes and by lacustrine algae. These occurred with a median spacing of $500 \mathrm{yr}$ (range: $200-1650 \mathrm{yr}$ ). We argue based on a correspondence between the macrophyte layers 
and higher $\delta^{18} \mathrm{O}$ values that these fluctuations were triggered by changes in lake level.

- At times during the last $4000 \mathrm{cal} \mathrm{yr}$, the lake was too shallow for sediment accumulation. The exact duration of the lowstand(s) is unknown due to the possibility of sediment erosion and/or deflation.

- Surface sediments in the lake accumulated during the 20th century. Their age is not well constrained, but we speculate that they correlate to a recent increase in monsoon strength (Anderson et al., 2002).

\section{Acknowledgments}

We thank J. Quade, D. Dettman and J. Shuttleworth for helpful discussions and two anonymous reviewers for helpful comments. This work was supported by grants from the NSF Earth System History program, NSF Graduate Fellowship program, NASA Space Grant program and Geological Society of America. We thank S. Trumbore, T. Jull, T. Lange and L. Hewitt for help with radiocarbon dating and S. Elias for insect identification. We thank H. Barnett, C. Urban-Evans, T. Dzienis and W. Wheeler for laboratory assistance.

\section{References}

An, Z., Porter, S.C., Kutzbach, J.E., Wu, X., Wang, S., Liu, X., Li, X., Zhou, W., 2000. Asynchronous Holocene optimum of the East Asian monsoon. Quaternary Science Reviews 19, 743-762.

Anderson, D.M., Overpeck, J.T., Gupta, A.K., 2002. Increase in the Asian southwest monsoon during the last four centuries. Science 297, 596-599.

Araguas-Araguas, L., Froehlich, K., Rozanski, K., 1998. Stable isotope composition of precipitation over southeast Asia. Journal of Geophysical Research 103, 28721-28742.

Baker, F.C., 1945. The Molluscan Family Planorbidae. University of Illinois Press, Urbana, Illinois.

Barnett, T.P., Dumenil, L., Schlese, U., Roeckner, E., 1988. The effect of Eurasian snow cover on global climate. Science 239, 504-507.

Blindow, I., Andersson, G., Hargeby, A., Johansson, S., 1993. Long-term pattern of alternative stable states in two shallow eutrophic lakes. Freshwater Biology 30, 159-167.

Chang, C., Shackleton, R.M., Dewey, J.F., Yin, J., 1988. The Geological Evolution of Tibet: Royal Society-Academia Sinica Geotraverse of the Qinghai-Xizang Plateau 1985. Royal Society, London.

Coops, H., Doef, R.W., 1996. Submerged vegetation development in two shallow, eutrophic lakes. Hydrobiologia 340, 115-120.

Deevey Jr., E.S., Gross, M.S., Hutchinson, G.E., Kraybill, H.L., 1954. The natural $14 \mathrm{C}$ contents of materials from hard-water lakes. Proceedings of the National Academy of Sciences 40, 285-288.

Douglas, R.W., Rippey, B., 2000. The random redistribution of sediment by wind in a lake. Limnology and Oceanography 45, 686-694.

Engel, S., Nichols, S.A., 1994. Aquatic macrophyte growth in a turbid windswept lake. Journal of Freshwater Ecology 9, 97-109.

Enzel, Y., Ely, L.L., Mishra, S., Ramesh, R., Amit, R., Lazar, B., Rajaguru, S.N., Baker, V.R., Sandler, A., 1999. High-resolution Holocene environmental changes in the Thar Desert. Northwestern India. Science 284, $125-128$.

Fleitmann, D., Burns, S.J., Mudelsee, M., Neff, U., Kramers, J., Mangini, A., Matter, A., 2003. Holocene forcing of the Indian monsoon recorded in a stalagmite from Southern Oman. Science 300, 1737-1739.

Fontes, J.-C., Gasse, F., Gibert, E., 1996. Holocene environmental changes in Bangong Co Basin (Western Tibet): Part 1. Chronology and stable isotopes of carbonates of a Holocene lacustrine core. Palaeogeography, Palaeoclimatology, Palaeoecology 120, 25-47.

Gaffey, S.J., Bronnimann, C.E., 1993. Effects of bleaching on organic and mineral phases in biogenic carbonates. Journal of Sedimentary Petrology 63, $752-754$.

Gasse, F., Van Campo, E., 1994. Abrupt post-glacial climate events in West Asia and North Africa monsoon domains. Earth and Planetary Science Letters 126, 435-456.

Gasse, F., Arnold, M., Fontes, J.-C., Fort, M., Gibert, E., Huc, A., Li, B., Li, Y., Liu, Q., Melieres, F., Van Campo, E., Wang, F., Zhan, Q., 1991. A 13,000 year climate record from western Tibet. Nature 353, 742-745.

Gasse, F., Fontes, J.-C., Van Campo, E., Wei, K., 1996. Holocene environmental changes in Bangong Co Basin (Western Tibet): Part 4. discussion and conclusions. Palaeogeography, Palaeoclimatology, Palaeoecology 120 , 79-92.

Grossman, E.L., Ku, T.L., 1986. Oxygen and carbon isotope fractionation in biogenic aragonite-Temperature effects. Chemical Geology 59, $59-74$.

Guo, Z., Petit-Maire, N., Kropelin, S., 2000. Holocene non-orbital climatic events in present-day arid areas of northern Africa and China. Global and Planetary Change 26, 97-103.

Hodell, D.A., Brenner, M., Kanfoush, S.L., Curtis, J.H., Stoner, J.S., Song, X., Wu, Y., Whitmore, T.J., 1999. Paleoclimate of southwestern China for the past 50,000 yr inferred from lake sediment records. Quaternary Research $52,369-380$.

Lister, G.S., Kelts, K., Chen, K., Yu, J., Niessen, F., 1991. Lake Qinghai, China: closed-basin lake levels and the oxygen isotope record for ostracoda since the latest Pleistocene. Palaeogeography, Palaeoclimatology, Palaeoecology $84,141-162$.

Liu, K.-B., Yao, Z., Thompson, L.G., 1998. A pollen record of Holocene climatic changes from the Dunde ice cap, Qinghai-Tibetan Plateau. Geology 26, 135-138.

Liu, Z., Kutzbach, J., Wu, L., 2000. Modeling climate shift of El Nino variability in the Holocene. Geophysical Research Letters 27, 2265-2268.

Lucas, W.J., Tyree, M.T., Petrov, A., 1978. Characterization of photosynthetic 14Carbon assimilation by Potamogeton lucens L. Journal of Experimental Botany 29, 1409-1421.

Meyers, P.A., 1994. Preservation of elemental and isotopic source identification of sedimentary organic matter. Chemical Geology 114, 289-302.

Moore, D.M., 1989. X-ray Diffraction and the Identification and Analysis of Clay Minerals. Oxford Univ. Press, New York.

Morinaga, H., Itota, C., Isezaki, H., Goto, H., Yaskawa, M., Kusakabe, J., Liu, Z., Gu, B., Cong, S., 1993. Oxygen-18 and carbon-13 records for the last 14,000 years from lacustrine carbonates of Siling-co lake in the QinghaiTibetan Plateau. Geophysical Research Letters 20, 2909-2912.

Morrill, C., 2004. The influence of Asian summer monsoon variability on the water balance of a Tibetan lake. Journal of Paleolimnology 32, $273-286$.

Morrill, C., Overpeck, J.T., Cole, J.E., 2003. A synthesis of abrupt changes in the Asian summer monsoon since the last deglaciation. The Holocene 13, $465-476$.

Overpeck, J., Anderson, D., Trumbore, S., Prell, W., 1996. The southwest Indian monsoon over the last 18,000 years. Climate Dynamics 12 , $213-225$.

Overpeck, J., Liu, K., Morrill, C., Cole, J., Shen, C., Anderson, D., Tang, L., 2005. Holocene environmental change in the Himalayan-Tibetan Plateau region: lake sediments and the future. In: Huber, U.M., Bugmann, H.K.M., Reasoner, M.A. (Eds.), Global Change and Mountain Regions: An Overview of Current Knowledge. Springer, Boston, pp. 83-92.

Pewe, T.L., Liu, T., Slatt, R.M., Li, B., 1995. Origin and Character of Loesslike Silt in the Southern Qinghai-Xizang (Tibet) Plateau, China. United States Geological Survey Professional Paper 1549 (55 pp.).

Prell, W.L., Kutzbach, J.E., 1992. Sensitivity of the Indian monsoon to forcing parameters and implications for its evolution. Nature 360, 647-652.

Scheffer, M., Hosper, S.H., Meijer, M.-L., Moss, B., Jeppesen, E., 1993. Alternative equilibria in shallow lakes. Trends in Ecology and Evolution 8, $275-279$.

Shen, C., 2003. Millennial-scale variations and centennial-scale events in the 
southwest Asian monsoon: pollen evidence from Tibet. PhD Dissertation, Louisiana State University. 286 pp.

Shukla, J., Paolino, D.A., 1983. The Southern oscillation and long-range forecasting of the summer monsoon rainfall over India. Monthly Weather Review 111, 1830-1837.

Staubwasser, M., Sirocko, F., Grootes, P.M., Erlenkeuser, H., 2002. South Asian monsoon climate change and radiocarbon in the Arabian Sea during early and middle Holocene. Paleoceanography, 17.

Stuiver, M., Reimer, P.J., Bard, E., Beck, J.W., Burr, G.S., Hughen, K.A., Kromer, B., McCormac, G., Van der Plicht, J., Spurk, M., 1998. INTCAL98 radiocarbon age calibration, 24,000-0 cal BP. Radiocarbon $35,215-230$

Thompson, L.G., Mosley-Thompson, E., Davis, M.E., Bolzan, J.F., Dai, J., Yao, T., Gundestrup, N., Wu, X., Klein, L., Xie, Z., 1989. Holocene-Late Pleistocene climatic ice core records from Qinghai-Tibetan Plateau. Science 246, 474-477.

Thompson, L.G., Yao, T., Davis, M.E., Henderson, K.A., Mosley-Thompson, E., Lin, P.-N., Beer, J., Synal, H.-A., Cole-Dai, J., Bolzan, J.F., 1997. Tropical climate instability: the last glacial cycle from a Qinghai-Tibetan ice core. Science 276, 1821-1825.

Tian, L., Yao, T., Numaguti, A., Sun, W., 2001. Stable isotope variations in monsoon precipitation on the Tibetan Plateau. Journal of the Meteorological Society of Japan 79, 959-966.

Verardo, D.J., Froelich, P.N., McIntyre, A., 1990. Determination of organic carbon and nitrogen in marine sediments using the Carlo Erba NA-1500 Analyzer. Deep-Sea Research 37, 157-165.

Verschuren, D., 1999. Sedimentation controls on the preservation and time resolution of climate-proxy records from shallow fluctuating lakes. Quaternary Science Reviews 18, 821-837.

Wang, B., French, H.M., 1995. Permafrost on the Tibet plateau, China. Quaternary Science Reviews 14, 255-274.

Wang, B., Wu, R., Lau, K.-M., 2001. Interannual variability of the Asian summer monsoon: contrasts between the Indian and the western North Pacific-East Asian monsoons. Journal of Climate 14, 4073-4090.

Wilks, D.S., 1995. Statistical Methods in the Atmospheric Sciences. Academic Press, San Diego.

Winkler, M.G., Wang, P.K., 1993. The late Quaternary vegetation and climate of China. In: Wright, H.E. (Ed.), Global Climates since the Last Glacial Maximum. University of Minnesota Press, Minneapolis, pp. 221-261.

Wright, H.E., Mann, D.H., Glaser, P.H., 1984. Piston corers for peat and lake sediments. Ecology 65, 657-659. 